\title{
Hubungan Self Confidence dan Adversity Quotient Terhadap Kemampuan Pemecahan Masalah Matematik Siswa
}

\section{Correlation of Self Confidence and Adversity Quotient Against Students' Mathematical Problem Solving Ability}

\author{
Rekma Mustika, Yurniwati \& Lukman El Hakim \\ Universitas Negeri Jakarta, Jakarta, DKI Jakarta, Indonesia \\ rekmamustika@gmail.com \\ Naskah diterima tanggal 9/6/2018, Direvisi akhir tanggal 15/7/2018, disetujui tanggal 15/8/2018
}

\begin{abstract}
Abstrak
Tujuan penelitian ini adalah untuk mempelajari hubungan SelfConfidence dan Adversity Quotient terhadap kemampuan pemecahan masalah matematika. Penelitian ini menggunakan pendekatan kuantitatif dengan metode survei. Populasi terjangkaunya adalah siswa SMP Negeri kelas VIII Kota Cilegon yang berjumlah 200 siswa. Hasil penelitian ini menunjukkan bahwa; 1) terdapat hubungan Self Confidence dengan Kemampuan Pemecahan Masalah; 2) terdapat hubungan Adversity Quotienty dengan Kemampuan Pemecahan Masalah; 3) terdapat hubungan antara Self Confidence dan Adversity Quotient secara bersama-sama dengan Kemampuan Pemecahan Masalah. Dengan demikian peningkatan kemampuan pemecahan masalah matematika dapat diraih dengan baik apabila adanya hubungan yang kuat Self Confidence dan Adversity Quotient. Kata kunci: Adversity quotient, Kemampuan pemecahan masalah matematik, dan Self Confidence.
\end{abstract}

\begin{abstract}
The purpose of this research is to learn the relationship of SelfConfidence and Adversity Quotient againstmathematical Problem Solving Ability. This research used quantitative approach with survey method. The population is students of junior high school grade VIII Cilegon City, amounting to 200 students. The results of this research were; 1) there is a relationship of Self Confidence with Problem Solving Ability; 2) there is relationship of Adversity Quotient with Problem Solving Ability; 3) there is relationship between Self Confidence and Adversity Quotient with Problem Solving Ability. Thus, improving the ability to solve mathematical problems can be achieved well if there is a strong relationship of Self Confidence and Adversity Quotient.
\end{abstract} Keywords: Adversity quotient, Mathematical problem solving ability, and Self confidence.

\section{PENDAHULUAN}

Matematika bukanlah pelajaran yang hanya memberikan pengetahuan kepada siswa mengenai bagaimana cara berhitung dan mengajarkan berbagai rumus, lebih dari itu matematika adalah pelajaran yang mengasah cara berpikir siswa agar siswa mampu berpikir secara logis, analitis, sistematis, dan kreatif.

Kompetensi yang harus dimiliki siswa adalah dalamkemampuanpemecahanmasalah matematik, menurut Hannula et al. (2004) pemecahan masalah dapat meningkatkan kualitas pengajaran matematika, "the problem-solving is defined as a teaching method that can improve the quality of teaching mathematics in schools". Belajar matematika adalah belajar menyelesaikan masalah sebagaimana yang dikatakan oleh Aydoğdu et all. (2008)bahwasannya, "some mathematicians say problem solving is at the heart of Mathematics". 
Dalam matematika, tidak semua pertanyaan merupakan suatu masalah. Suatu pertanyaan akan menjadi masalah jika pertanyaan itu menunjukkan adanya suatu tantangan yang tidak dapat diselesaikan dengan prosedur rutin yang sudah diketahui oleh siswa. Shadiq (2004) menyarankan bahwa dalam memecahkan masalah dilengkapi dengan pengembangan keterampilan memberikan penjelasan dan mengkomunikasikan hasil pemecahan masalah.

Sejalan dengan hal di atas, seperti yang telah dirumuskan oleh Dewan Guru Nasional Matematika di Amerika Serikat, NCTM dan tercantum dalam buku yang berjudul 'Principles and Standard for School Mathematics' pada tahun 2000 menyatakan bahwa pemecahan masalah (problem solving), penalaran dan pembuktian (reasoning and proof), komunikasi matematis (communication), keterkaitan dalam matematika (connection), dan representasi (representation) merupakan standar proses dalam pembelajaran matematika. Begitu juga menurut The Program for International Student Assessment (PISA) yang melibatkan dan mengukur kemampuan problem solving, menyatakan bahwa kemampuan anak didik di negara Republik Indonesia berada pada level rendah dengan skor 375, peringkat 64 dari 65 negara peserta, situasi yang merisaukan ini selalu berada pada level bawah, sejak keikut sertaannya tahun 2000 peringkat 39 dari 43 peserta, tahun 2003 peringkat 38 dari 41, tahun 2006 peringkat 50 dari 57, dan tahun 2009 peringkat 61 dari 65 (PISA: 2012).

Faktor penyebab kelemahan anak didik Indonesia, salah satunya adalah karena kurang kompeten dalammengorganisasikan dan menyimpulkan informasi. Kenyataan di lapangan, pembelajaran matematika belum sepenuhnya dapat mengembangkan kemampuan matematis siswa seperti kemampuan pemecahan masalah matematis. Rendahnya kemampuan pemecahan masalah matematis siswa tentu sangat memprihatinkan tenaga pendidik.

Manusia pada dasarnya memiliki beberapa kemampuan dalam dirinya baik kemampuan teknis (hard skill) maupun kemampuan non teknis (soft skill). Menurut penelitian di Harvard University Amerika Serikat ternyata kesuksesan seseorang tidak ditentukan semata-mata oleh pengetahuan dan kemampuan teknis semata, tetapi lebih oleh kemampuan mengelola diri dan orang lain (soft skill), senada dengan penelitian yang dilakukan oleh Erus Angelo A. Lumague (2017) mengenai pentingnya hard skill dan soft skill, menyatakan bahwa, "the implications of hard and soft skills will have an impact on the company, the company will benefit in knowing the relative value of the hard and soft skills of its employees". Mengingat pentingnya soft skill dalam keberhasilan seseorang maka pada bagian ini akan dibahas salah satunya yaitu selfconfidence. Self-confidence sangat penting untuk siswa agar dapat berhasil dalam belajar matematika (Yates, 2002: 5). Dimana selfconfidence itu sendiri adalah kepercayaan pada kemampuan diri yang muncul sebagai akibat adanya dinamika atau proses yang positif di dalam diri seseorang. Keberhasilan yang ditentukan oleh self-confidence juga berlaku di sekolah. Salah satu self-confidence yang harus dipupuk di sekolah adalah dalam 
bidang matematika. Hal ini disebabkan matematika merupakan salah satu pelajaran yang banyak dihindari siswa karena dianggap sukar. dengan menumbuhkan dan memupuk self-confidence siswa diharapkan akan lebih berani memecahkan persoalan yang berkaitan dengan kemampuan pemecahan masalah matematik yang ada sebagaimana yang dikatakan oleh Surya, E, dkk (2017)didalam penelitiannya menyatakan self-confidence berepngaruh positif terhadap kemampuan pemecahan masalah matematika.

Hudojo (1990) mengemukan bahwa suatu soal atau pertanyaan dikatakan masalah tergantung pada pengetahuan yang dimiliki penjawab. Hudojo (2000) membagi masalah dalam matematika ke dalam enam jenis sebagai berikut:

1. Masalah rutin adalah masalah yang prosedur penyelesaiannya sekedar mengulang, misalnya secara algoritmik.

2. Masalah nonrutin adalah masalah yang prosedur penyelesaiannya memerlukan perencanaan penyelesaian, tidak sekedar menggunakan rumus, teorema atau dalil.

3. Masalah rutin-terapan adalah masalah rutin yang dikaitkan dengan dunia nyata atau kehidupan sehari-hari, yang prosedur penyelesaiannya standar sebagaimana yang diajarkan.

4. Masalah rutin-nonterapan adalah masalah rutin yang lebih ke matematikanya daripada dikaitkan dengan dunia nyata atau kehidupan sehari-hari.

5. Masalah nonrutin-terapan adalah masalah yang penyelesaiannya menuntut perencanaan dengan mengaitkan dunia nyata atau kehidupan sehari-hari.

6. Masalah nonrutin-nonterapan adalah masalah yang berkaitan murni tentang hubungan matematika.

Jenis-jenis masalah yang dikemukan di atas, maka pada penelitian ini masalah yang akan diambil adalah jenis masalah non rutin dan masalah menemukan. Masalah non rutin adalah masalah yang penyelesaiannya memerlukan perencanaan, dan bukan hanya mengandalkan rumus semata.

Suatu masalah dalam pembelajaran matematika dapat diartikan berbeda dalam setiap individu yang menghadapinya karena ada orang yang menganggap suatu masalah itu merupakan suatu masalah tetapi individu lain tidak menganggapnya sebagai suatu masalah. Masalah perlu untuk diselesaikan dan dipecahkan. Polya (1973) menyatakan bahwa memecahkan berarti menemukan maksud atau makna yang tidak diketahui untuk mendapatkan penyelesaian yang jelas. Dahar (1988: 167) menyatakan bahwa kegiatan pemecahan masalah itu sendiri merupakan keinginan manusia dalam menerapkan konsep-konsep dan aturan-aturan yang diperoleh sebelumnya. Pendapat tersebut didukung oleh Sumarmo (2000) yang menyatakan bahwa pemecahan masalah adalah suatu proses untuk mengatasi kesulitan yang ditemui untuk mencapai suatu tujuan yang diinginkan.

NCTM (2000) menyebutkan bahwa pemecahan masalah merupakan salah satu fokus utama dalam pembelajaran matematika. Belajar matematika pada dasarnya seseorang tidak terlepas dari masalah karena berhasil atau tidaknya seseorang dalam matematika 
ditandai adanya kemampuan dalam menyelesaikan masalah yang dihadapinya. Ketika seseorang memecahkan masalah, ia perlu memahami masalah yang muncul. Sesuatu yang menurutnya merupakan masalah, belum tentu menurut orang lain. Dindyal (2005), suatu situasi disebut masalah jika terdapat kendala pada kemampuan pemecahan masalah. Adanya kendala tersebut menyebabkan seorang pemecah masalah tidak dapat memecahkan masalah secara langsung.

Siswa yang mengalami kesulitan untuk menyelesaikan permasalahan matematika diharapkan jangan putus semangat, dan terus berusaha untuk mencari jalan penyelesaian terhadap permasalahan matematika tersebut. Untuk menyelesaiakn permasalahan matematika tersebut dibutuhkan daya juang siswa tersebut agar meraih hasil yang maksimal. Ketangguhan dan daya juang inilah yang dikonseptualisasikan oleh Paul G. Stoltz (2000) sebagai kecerdasan ketegaran atau daya juang atau disebut juga dengan adversity quotient. Kemudian Stoltz (2000) mengajukan teorimengenai adversity quotient yang menurutnya dapat menjembatani antara IQ dan EQ seseorang. Individu atau siswa adversity quotient dapat mengubah hambatan menjadi sebuah peluang karena kecerdasan ini menjadi penentu seberapa jauh individu mampu bertahan dalam menghadapi dan mengatasi kesulitan Stoltz (2000).

Adversity quotient sangat penting untuk dimiliki karena pada saat pembelajaran, siswa dituntut untuk mengerahkan kemampuan matematiknya khususnya kemampuan pemecahan masalah jika sewaktu-waktu muncul kesulitan dan hambatan dalam menyelesaikan masalah matematik tersebut. Rendahnya kemampuan pemecahan masalah matematik siswa, self-confidence siswa untuk menyelesaikan masalah yang rendah, adversity quotient siswa yang masih rendah juga, merupakan kendala dan masalah dalam kelangsungan proses belajar mengajar. Masalah dalam belajar adalah suatu kondisi tertentu yang dialami oleh siswa dalam hal menghambat kelancaran proses belajarnya, dan masalah dalam belajar tidak hanya dialami oleh siswa yang terbelakang, tetapi juga dapat menimpa siswa yang pandai Nasir, S (2008).

Berdasarkan uraian di atas, maka dapat diketahui bahwa kemampuan seorang siswa dalam menyelesaikan permasalahan matematika, dapat dipengaruhi oleh oleh kepercayaan kemampuan diri yang muncul dari suatu proses yang positif, dan dapat juga dilihat dari daya juang atau kegigihan sehingga dapat mendorong seseorang untuk mengeluarkan kemampuannya dalam menyelesaikan permasalahan yang berhubungan dengan matematika.

Montague (2007)mengatakan bahwa pemecahan masalah matematis adalah suatu aktivitas kognitif yang kompleks yang disertai sejumlah proses dan strategi. Untuk memecahkan masalah diperlukan langkah-langkah konkrit yang tepat sehingga diperoleh jawaban yang benar.

NCTM (2000) mengemukakan bahwa pemecaham masalah merupakan proses menerapkan pengetahuan yang telah diperoleh sebelumnya pada situasi baru yang berbeda. Selainitu NCTM juga mengungkapkan tujuan pengajaran pemecahan masalah secara umum adalah untuk (1) membangun pengetahuan 
matematika baru, (2) memecahkan masalah yang muncul dalam matematika dan di dalam konteks-konteks lainnya, (3) menerapkan dan menyesuaikan bermacam strategi yang sesuai untuk memecahkan permasalahan dan (4) memantau dan merefleksikan proses dari pemecahan masalah matematika.

Berdasarkan uraian di atas, maka indikator kemampuan pemecahan masalah matematik pada penelitian ini adalah sebagai berikut: (a) menyelesaikan masalah dari situasi seharihari ke dalam matematika, (b) menyelesaikan masalah di luar konteks matematika, (c) menerapkan dan mengadaptasi berbagai strategi untuk memecahkan masalah matematika.

Fishbein \& Ajzen (Hapsari, 2011: 2) menyatakan,"self-confidence is a belief", kepercayaan diri adalah sebuah keyakinan. Keyakinan menurut Scoenfeld (Hannula et all., 2004: 17) adalah pemahaman dan perasaan individu yang membentuk cara bahwa konsep individu yang terlibat dalam perilaku matematika.

Menurut Lie (Holikulanwar, 2012) Seseorang yang percaya diri dapat menyelesaikan tugas atau pekerjaan yang sesuai dengan tahapan perkembangan dengan baik,merasaberharga,mempunyaikeberanian, dan kemampuan untuk meningkatkan prestasinya, mempertimbangkan berbagai pilihan, serta membuat keputusan sendiri merupakan perilaku yang mencerminkan percaya diri.

Sejalan dengan hal tersebut menurut AlUqshari (2005) percaya diri adalah salah satu kunci kesuksesan hidup individu. Karena tanpa adanya percaya diri, individu tidak akan sukses dalam berinteraksi dengan orang lain. Fatimah, E (2006) yang menyatakan bahwa percaya diri adalah sikap positif seorang individu yang memampukan diri sendiri maupun terhadap lingkungan atau situasi yang dihadapinya.

Bandura (Sudrajat, 2008) menyatakan bahwa kepercayaan diri adalah percaya terhadap kemampuan diri dalam menyatukan dan menggerakkan motivasi dan sumber daya yang dibutuhkan, dan memunculkannya dalam tindakan yang sesuai dengan apa yang harus diselesaikan, atau sesuai dengan tuntutan tugas. Self-confidence menurut Ghufron dan Rini (2011) adalah keyakinan untuk melakukan sesuatu pada diri subjek sebagai karakteristik pribadi yang di dalamnya terdapat kemampuan diri, optimis, objektif, bertanggung jawab, rasional, dan realistis.

Adversity berasal dari kata adverse yang artinya kemalangan atau kesulitan, dan dapat dijabarkan sebagai suatu kondisi dari ketidakbahagiaan, kesulitan atau ketidakberuntungan. Menurut (Hawadi, 2004) quotient kamus bahasa inggris adalah derajat atau jumlah dari kualitas spesifik atau karakteristik, atau dengan kata lain yaitu mengukur kemampuan seseorang.

Adversity quotient diungkapkan oleh Stoltz (2000) sebagai kemampuan seseorang dalam mengamati kesulitan dan mengolah kesulitan tersebut dengan kecerdasan yang dimiliki sehingga menjadi sebuah tantangan untuk menyelesaikannya. Terutama dalam menggapai sebuah tujuan, cita-cita, harapan, dan yang paling penting adalah kepuasan pribadi dari hasil kerja atau aktivitas itu sendiri.

Potensi adversity quotient sangat 
dibutuhkan dalam menghadapi kesulitan, karena pada dasarnyabelajaradalah mengatasi kesulitan, sehingga peran adversity quotient dapat mempengaruhi tingkat ketahanan siswa dalam menghadapi kesulitan-kesulitan tersebut. Sikap inilah yang perlu ditanamkan kepada siswa dalam belajar matematika. Adversity quotient dapat dikelompok menjadi tiga tipe siswa, dimana dalam hal ini melihat sikap dari siswa tersebut dalam menghadapi setiap masalah dan tantangan hidupnya. Kelompok atau tipe siswa tersebut antara lain adalah (Stolzt, 2000):

\section{Quitters (Low Adversity Quetiont)}

Tipe quitters, mereka yang berhenti adalah seseorang yang memilih untuk keluar, menhindari kewajiban, mundur dan berhenti apabila menghadapi kesulitan. Orang-orang jenis ini berhenti di tengah pendakian, gampang putus asa, menyerah (Ginanjar, 2001: 271). Orang dengan tipe ini cukup puas dengan pemenuhan kebutuhan dasar atau fisologis saja dan cenderung pasif, memilih untuk keluar menghindari perjalanan, selanjutnya mundur dan berhenti. Para quitters menolak menerima tawaran keberhasilan yang disertai dengan tantangan dan rintangan. Orang yang seperti ini akan banyak kehilangan kesempatan berharga dalam kehidupan. Dalam hirarki Maslow tipe ini berada pada pemenuhan kebutuhan fisiologis yang letaknya paling dasar dalam bentuk piramida.

\section{Campers (Middle Adeversity Quotient)} Tipe campers atau satis-ficer (dari kata satisfied $=$ puas dan suffice $=$ mencukupi). Golongan ini puas dengan mencukupkan diri dan tidak mau mengembangkan diri. Tipe ini merupakan golongan yang sedikit lebih banyak, yakitu mengusahakan terpenuhinya kebutuhan keamanan dan rasa aman pada skala hirarki Maslow. Kelompok ini juga tidak tinggi kapasitasnya untuk perubahan karena terdorong oleh ketakutan dan hanya mencari keamanan dan kenyamanan. Campers setidaknya telah melangkah dan menanggapi tantangan, tetapi setelah mencapai tahap tertentu, campers berhenti meskipun masih ada kesempatan untuk lebih berkembang lagi. Berbeda dengan quitters, campers sekurangkurangnya telah menanggapi tantangan yang dihadapi sehingga telah mencapai tingkat tertentu.

\section{Climbers (HighAdversity Quotient)}

Tipe climbers (pendaki) mereka yang selalu optimis, melihat peluang-peluang, melihat celah, melihat senoktah harapan di balik keputusasaan, dan selalu bergairah untuk maju. Noktah kecil yang dianggap sepele, bagi para Claimbers mampu dijadikan sebagai cahaya pencerah kesuksesan (Ginanjar, 2001: 17). Climbers merupakan kelompok orang yang selalu berupaya mencapai puncak kebutuhan aktualisasi diri pada hirarki Maslow. Climbers adalah tipe manusia yang berjuang seumur hidup, tidak peduli sebesar apapun kesulitan yang datang. Climbers tidak dikendalikan oleh lingkungan, tetapi dengan berbagai kreatifitasnya tipe ini berusaha mengendalikan lingkungannya. Climbers akan selalu memikirkan berbagai alternatif permasalahan dan menganggap kesulitan dan rintangan yang ada justru menjadi peluang untuk lebih maju, berkembang, dan mempelajari lebih banyak lagi tentang kesulitan hidup. Tipe ini akan selalu siap menghadapi berbagai rintangan dan menykai tantangan yang diakibatkan oleh adanya 
perubahan-perubahan.

Stoltz (2000: 140) menawarkan empat dimensi dasar yang akan menghasilkan kemampuan adversity quotient yang tinggi, yaitu:

\section{Control (Kendali Diri)}

Kendali berkaitan dengan seberapa besar orang merasa mampu mengendalikan kesulitan-kesulitan yang dihadapinya dan sejauh mana individu merasa bahwa kendali itu ikut berperan dalam peristiwa yang menimbulkan kesulitan. Semakin besar kendali yang dimiliki semakin besar kemungkinan seseorang untuk dapat bertahan menghadapi kesulitan dan tetap teguh dalam niat serta ulet dalam mencari penyelesaian. Demikian sebaliknya, jika semakin rendah kendali, akibatnya seseorang menjadi tidak berdaya menghadapi kesulitan dan mudah menyerah.Kemampuan siswa dalam mempengaruhi secara positif suatu situasi serta mampu mengendalikan respon terhadap situasi, dengan pemahaman awal bahwa sesuatu apapun dalam situasi apapun siswa dapat melakukannya. Dimensi ini menjelaskan mengenai bagaimana siswa memiliki kendali dalam suatu masalah yang muncul. Apakah siswa memandang bahwa dirinya tak berdaya dengan adanya masalah tersebut atau atau ia dapat memegang kendali dari akibat masalah tersebut.

2. Origin dan Ownership (Asal-Usul dan Pengakuan Diri)

Suatu kemampuan individu dalam menempatkan perasaan dirinya dengan berani menanggung akibat dari situasi yang ada, sehingga mampu menciptakan perbaikan atas masalah yang terjadi. Dimensi ini menjelaskan mengenai bagaimana siswa memandang sumber masalah yang ada. Apakah ia cenderung memandang masalah yang terjadi bersumber dari dirinya seorang atau ada faktor-faktor lain di luar dirinya. Selain itu, dimensi ini menjelaskan tentang bagaimana siswa mengakui akibat dari masalah yang timbul. Apakah ia cenderung tak peduli dan lepas tanggung jawab atau mau mengakui dan mencari solusi untuk masalah tersebut.

\section{Reach (Jangkauan)}

Kemampuan individu dalam menjangkau dan membatasi masalah agar tidak menjangkau bidang-bidang yang lain. Dimensi ini menjelaskan tentang bagaimana suatu masalah yang muncul dapat mempengaruhi segi-segi hidup yang lain dari orang tersebut. Apakah ia cenderung memandang masalah tersebut meluas atau hanya terbatas masalah tersebut saja. Semakin tinggi jangkauan seseorang, semakin besar kemungkinannya dalam merespon kesulitan sebagai sesuatu yang spesifik dan terbatas. Semakin efektif dalam menahan atau membatasi jangkauan kesulitan, maka seseorang akan lebih berdaya dan perasaan putus asa atau kurang mampu membedakan hal-hal yang relevan dengan kesulitan yang ada, sehingga ketika memiliki masalah di satu bidang dia tidak harus merasa mengalami kesulitan untuk seluruh aspek kehidupan individu tersebut.

\section{Endurance (Daya Tahan)}

Kemampuan individu dalam mempersepsikan kesulitan dan kekuatan dalam menghadapi kesulitan tersebut dengan menciptakan ide-ide dalam mengatasi masalah sehingga ketegaran hati dan keberanian dalam penyelesaian masalah dapat terwujud. Dimensi ini menjelaskan tentang bagaimana siswa 
memandang jangka waktu berlangsungnya masalah yang muncul. Apakah ia cenderung untuk memandang masalah tersebut secara permanen dan berkelanjutan atau hanya dalam bersifat sementara.

Berdasarkan teori yang telah diungkapkan, maka advertisy quotient adalah suatu kemampuan yang ada dalam diri seseorang untuk mengatasi dan mengolah kesulitan dengan menggunakan kecerdasan yang dimiliki sehingga menjadikannya sebuah tantangan untuk diselesaikan, dengan dimensi adversity quotient yang menjadi indikatornya berupa control (kendali diri), origin dan ounership (asal-usul dan pengakuan diri, reach (jangkauan), dan endurance (daya tahan) seseorang terhadap suatu kesulitan sehingga sampai pada tujuannya.

\section{METODE PENELITIAN}

Metode penelitian yang akan digunakan dalam penelitian ini yaitu survei untuk melihat adanya pengaruh linear antara self confidence dan adversity quotient terhadap kemampuan pemecahan masalah matematik. Penelitian survei merupakan penelitian yang menggunakan sampel dari populasi dengan alat pengumpul data yang disebut instrumen berbentuk kuisioner atau angket atau tes. Variabel-variabel yang ada dalam penelitian ini terdiri dari variabel indenpenden dan variabel variabel dependen. Variabel indenpenden terdiri dari variabel self confidence ${ }^{\left(X_{1}\right)}$ dan variabel adversity quotient ${ }^{\left(X_{2}\right)}$. Sedangkan variabel dependen, yaitu kemampuan pemecahan masalah matematik $(Y)$.

Populasi yang menjadi target dalam penelitan ini adalah seluruh siswa SMP Negeri Kota Cilegon. Populasi terjangkaunya adalah siswa SMP Negeri kelas VIII Kota Tengah yang berjumlah 400 siswa dan diperoleh sampel berjumlah 200 siswa.

\section{HASIL DAN PEMBAHASAN}

Beberapa pembahasan dan interpretasi hasil penelitian di atas secara lebih mendalam dijelaskan di bawah ini.

1. Hubungan Self Confidence dengan Kemampuan Pemecahan Masalah

\begin{tabular}{|c|c|c|c|c|c|c|}
\hline \multirow{3}{*}{\multicolumn{2}{|c|}{ Model }} & \multirow{2}{*}{\multicolumn{2}{|c|}{$\begin{array}{l}\text { Unstandardized } \\
\text { Coefficients }\end{array}$}} & \multirow{3}{*}{$\begin{array}{c}\text { Standardized } \\
\text { Coefficients } \\
\text { Beta }\end{array}$} & \multirow[t]{3}{*}{$\mathrm{T}$} & \multirow[t]{3}{*}{ Sig. } \\
\hline & & & & & & \\
\hline & & $\mathrm{B}$ & Std. Error & & & \\
\hline \multirow[t]{2}{*}{1} & (Constant) & $-46,400$ & 5,481 & & $-8,466$ & 000 \\
\hline & Self-Confidence (X1) & ,592 &, 050 & 645 & 11,869 &, 000 \\
\hline
\end{tabular}

a Dependent Variable: Kemampuan Pemecahan Masalah (Y)

Berdasarkan Tabel 1 diperoleh $t_{\text {hitung }}$ sebesar 11,869 dan nilai probabilitas (Sig.) sebesar 0,000. Diketahui ${ }^{t_{\text {tabel }}}$ pada uji dua arah dengan taraf signifikan 0,01, jumlah responden $^{(n)}=200$ orang dan derajat bebas $(d b) n-2=198$ adalah sebesar 2,60. Karena $t_{\text {hitung }}(11,869)>t_{\text {tabel }}(2,60)>$ dan nilai probabilitas, maka terbukti bahwa hipotesis $H_{0}$ ditolak dan $H_{1}$ diterima yang berarti terdapat hubungan yang sangat signifikan antara self confidence dengan kemampuan pemecahan masalah matematik. Hal ini sesuai 
dengan pendapat Mafakheri, Shiva (2013), yang menunjukan saling ketergantungannya self-confidence dan kemampuan pemecahan masalah, penelitian ini bertujuan untuk mengetahui faktor-faktor yang berpengaruh terhadap self-confidence dan problem solving. Hubungan yang saling menguntungkan tersebut dapat berupa keyakinan seseorang dalam usaha mencari untuk mencari jalan keluar dari suatu kesulitan, guna mencapai suatu tujuan yang tidak begitu mudah untuk segera dicapai. Selalu bersikap optimis, tenang, dan pantang menyerah dalam setiap permasalahan matematika.

MenurutJagals(2004) dalam penelitiannya menunjukan terdapat hubungan antara selfconfidence dengan pemecahan masalah matematika "participants recalled not only low confidence connected to unsuccessful experiences with problem solving, but also moments when their confidence was high and performance successful". Siswa yang memiliki self-confidence akan melakukan segala sesuatu secara optimal, dapat membantu orang lain, dan mampu menghadapi segala kendala, memahami perasaan sendiri, mengungkapkan perasaan sendiri, memeroleh kasih sayang, perhatian disaat orang lain mengalami kesulitan, dan memahami manfaat pada apa yang dapat disumbangkan kepada orang lain, memahami bahwa alam semesta adalah sebuah misteri, meyakini takdir tuhan, dan menganggap tuhan.

2. Hubungan Adversity Quotient dengan Kemampuan Pemecahan Masalah Tabel 2.Hasil Uji Signifikan Koefisien Korelasi antara $\left(X_{2}\right) \operatorname{dengan}\left({ }^{Y}\right)$

\begin{tabular}{|c|c|c|c|c|c|c|}
\hline & \multirow{3}{*}{ Model } & \multirow{2}{*}{\multicolumn{2}{|c|}{$\begin{array}{l}\text { Unstandardized } \\
\text { Coefficients }\end{array}$}} & \multirow{2}{*}{$\begin{array}{l}\text { Standardized } \\
\text { Coefficients }\end{array}$} & \multirow{3}{*}{$\mathrm{t}$} & \multirow{3}{*}{ Sig. } \\
\hline & & & & & & \\
\hline & & B & Std. Error & Beta & & \\
\hline \multirow[t]{2}{*}{1} & (Constant) & $-46,375$ & 6,148 & & 7,544 &, 000 \\
\hline & Adversity Quotient (X2) & ,558 & ,053 & 601 & 10,575 & ,000 \\
\hline
\end{tabular}

a Dependent Variable: Kemampuan Pemecahan Masalah (Y)

Berdasarkan Tabel 2 diperoleht $_{\text {hitung }}$ sebesar 10,575 dan nilai probabilitas (Sig.) sebesar 0,000 . Diketahui $t_{\text {tabel }}$ pada uji dua arah dengan taraf signifikan 0,05 , jumlah responden (n) 200 orang dan derajat bebas $(\mathrm{db}) \mathrm{n}-2=198$ adalah sebesar $-2,60$, Karenat $_{\text {hitung }}(10,575)>$ $\mathrm{t}_{\text {tabel }}(2,60)$ dan nilai probabilitas Sig. $(0,000)$ $<$ taraf signifikan $(0,01)$, maka terbukti bahwa hipotesis $\mathrm{H}_{0}$ ditolak dan $\mathrm{H}_{1}$ diterima yang berarti terdapat hubungan yang sangat signifikan antara Self Confidencedengan kemampuan pemecahan matematik. Hasil analisis ini memberikan petunjuk bahwa adversity quotient merupakan salah satu faktor utama yang berkonstribusi terhadap kemampuan pemecahan masalah.

Dari hasil itu pula dapat diinterpretasikan bahwa peningkatan adversity quotient akan memberikan konstribusi yang berarti terhadap kemampuan pemecahan masalah. Hal ini sesuai dengan pendapat Mardika, F (2017) menyatakan bahwa "adversity quotient has a relationship with problem solving skills. Each student will be facing problems in the study of mathematics, but the important thing is how the right way to overcome these problems". Adversity quotient memiliki hubungan dengan kemampuan memecahkan 
masalah. Senada dengan penelitian yang dilakukan Sahyar \& Fitri (2017) yang menyatakan bahwa pentingnya adversity quotient terhadap kemampuan pemecahan masalah "the adversity quotient important role in improving students' problem-solving ability"

Siswa yang memiliki adversity quotient yang lebih tinggi lebih berani mengambil resiko, sehingga tuntutan dan harapan dijadikan sebagai dukungan dan keberadaan di kelas merupakan peluang untuk menyelesaikan permasalahan dengan baik.

3. Hubungan antara Self Confidence dan Adversity Quotient Secara Bersamasama terhadap Kemampuan Pemecahan Masalah Matematik

Tabel 3. Hasil Uji Signifikansi Regresi Ganda

\begin{tabular}{ll|rrrrrr}
\hline \multicolumn{2}{c}{ Model } & & $\begin{array}{c}\text { Sum of } \\
\text { Squares }\end{array}$ & Df & Mean Square & F & \multicolumn{1}{c}{ Sig. } \\
\hline 1 & Regression & 2369,158 & 2 & 1184,579 & 10,987 &, $000(\mathrm{a})$ \\
\hline Residual & 2121,717 & & 197 & & 10,770 & & \\
\hline Total & 4490,875 & & 199 & & & & \\
\hline
\end{tabular}

a Predictors: (Constant), Mathematics Anxiety (X2), Self-Efficacy (X1)

b Dependent Variable: Kemampuan Pemecahan Masalah (Y)

Berdasarkan Tabel 3 di atas didapat nilai $\mathrm{F}_{\text {hitung }}$ sebesar 10,987 dengan nilai probabilitas (Sig.) sebesar 0,000. Untuk menentukan keberartian persamaan regresi ganda perlu membandingkan dengan tabel distribusi $\mathrm{F}$ dengan menggunakan $\mathrm{db}$ pembilang $=1$ dan $d b$ penyebut $(n-2)=248$ dengan taraf signifikan $(\alpha)$ 0,01. Diperoleh $F_{\text {tabel }}$ sebesar 4,71 dan $\mathrm{F}_{\text {hitung }}$ sebesar 10,987. Hal ini menunjukkan bahwa $\mathrm{F}_{\text {hitung }}(10,987)>\mathrm{F}_{\text {tabel }}$ $(4,71)$ dan nilai probabilitas $(0,000)<$ taraf signiikan $(0,01)$ maka persamaan regresi ganda sudah layak untuk memprediksi hubungan Self Confidence dan Adversity Quotient terhadap kemampuan pemecahan masalah matematik. Berdasarkan Tabel 5 didapat besarnya koefisien korelasi ganda 0,726 yang berarti bahwa 52,8\% proporsi varians kemampuan pemecahan masalah dapat dijelaskan secara bersama-sama oleh self confidenceAdversity Quotient.

Hal ini sesuai dengan pendapat Suryadi, B (2017)dalam penelitiannya menjelaskan bahwa, "this study has shown that selfconfidence and the adversity quotient are two determining factors for students, mathematics achievement. About 13\% of students' achievement in mathematics was determined by self-confidence and the adversity quotient".

\section{KESIMPULAN}

Dari analisis dan pembahasan yang sudah disajikan pada bab sebelumnya dapat disimpulkan diantaranya; Self-confidence memiliki hubungan positif dan signifikan dengan kemampuan pemecahan masalah siswa SMP Negeri di Kota Cilegon, Provinsi Banten. Ini berarti bahwa semakin tinggi self-confidence siswa maka semakin tinggi pula kemampuan pemecahan masalahnya, Adversity quotient memiliki hubungan positif dengan kemampuan pemecahan masalah siswa SMP Negeri di Kota Cilegon, Provinsi Banten. Ini berarti bahwa semakin tinggi adversity quotient siswa maka semakin tinggi 
pula kemampuan pemecahan masalahnya, Self-confidence dan adversity quotient secara bersama-sama memiliki hubungan positif dan signifikan dengan kemampuan pemecahan masalah siswa SMP Negeri di Kota Cilegon,
Provinsi Banten. Ini berarti bahwa semakin tinggi kemampuan self-confidence dan adversity quotient siswa maka semakin tinggi pula kemampuan pemecahan masalahnya.

\section{DAFTAR PUSTAKA}

Al-Uqshari, Y. (2005). Percaya Diri. Jakarta: Gema Insani.

Aydoğdu.,Mustafa., \&Ayaz, M. F. (2008). The Importance Of Problem Solving In Mathematics Curriculum.eJournal of New World Sciences Academy, Volume: 3, Number: 4.

Fatimah, E. (2006). Psikologi Perkembangan. Bandung: Balai Setia.

Gufron., \& Rini, R.S. (2011). “Teori-teori Psikologi.” Yogyakarta: Ar-Ruzz Media.

Hannula, M. S., Maijala, M., \& Pehkonen, E. (2004). Development of Understanding Self-Confidence in Mathematics; Grade 5-8. Group for Psychology of Mathematics Education. Vol. 3, pp 17-24.

Hapsari, M. J. (2011). Upaya Meningkatkan Self-Confidence Siswa dalam Pembelajaran Matematika melalui Model Inkuiri Terbimbing. [online]. Tersedia: http://fmipa.uny.ac.id/semnasmatematika/content/ mahrita-julia-hapsari-s-pd. [Akses 30 Desember 2014].

Hawadi, R. A. (2004). “Kiat-kiat Mementapkan Adversity Quotient Siswa Akseleran”, dalam Akselerasi A-Z Informasi Program Percepatan Belajar dan Anak Berbakat Intelektual. Jakarta: PT. Gramedia Widiasarana Indonesia.

Hudojo, H. (1990). Strategi Belajar Mengajar Matematika. Malang: IKIP Malang.

Jagals, D. M. (2004).Mathematics Confidence: Reflections On Problem-Solving Experiences, Proceedings of the 28th Conference of the International Group for the Psychology of Mathematics Education.

Mardika, F. (2017). Adversity Quotient and Students' Problem Solving Skill in Mathematics, $4^{\text {th }}$ ICRIEMS Proceedings, Published by The Faculty Of Mathematics And Natural Sciences Yogyakarta State University.

Montaque, M. (2007). “Math Problem Solving for Middle School Students with Disabilities.” [Online]. Avaliable: http://www.k8accesscenter.org/trainingresources/Math Problem Solving.asp. [Akses 30 Desember 2014].

Nasir, S. (2008). MeningkatkanKemampuan Koneksi dan pemecahan Masalah Matematik Siswa SMA yang berkemampuan Rendah Melalui Pendekatan Konstektual. Tesis PPS UPI. Tidak diterbitkan.

NCTM. (2000). [Online]. Using The NCTM 2000 Principles and Standards with The Learning from Assessment Materials.http://www.wested.org/Ifa/NCTM2000.PDF. [Akses: 22 Desember 2014].

Polya, G. (1973). How to Solve It: A New Aspect of Mathematical Method. Second Edition. New Jersey: Princeton University Press.

Sahyar.,\& Fitri. R. Y. (2017). The Effect of Problem-Based Learning Model (PBL) and Adversity Quotient (AQ) on Problem-Solving Ability, American Journal of Educational Research, Vol. 5, No. 2, 179-183.

Shadiq, F. (2004). Pemecahan Masalah Penalaran dan Komunikasi. [Online]. Tersedia: http://www.scribd.com./ doc/29385462/Modul-Matematika-Pemecahan-Masalah

Stoltz, P. G. (2000). Adversity Quotient, Mengubah Hambatan Menjadi Peluang. Terjemahan. Jakarta:PT. Gramedia Widiasarana Indonesia.

Sudrajat, D. (2008). Program Pengembangan Self Efficacy Bagi Konselor di SMA Negeri Se-Kota Bandung. Tesis. UPI: tidak diterbitkan.

Surya, E., Putri, F. A., \& Mukhtar. (2017).Improving Mathematical Problem-Solving Ability And Self-Confidence Of High School Students Through Contextual Learning Model. Journal on Mathematics Education, Volume 8, No. 1 